\title{
KONCEPT KVALITY ŽIVOTA V ROZVOJOVÝCH STRATEGIÍCH MIKROREGIONŮ JIHOMORAVSKÉHO KRAJE
}

\section{QUALITY OF LIFE CONCEPT IN DEVELOPMENT STRATEGIES OF} MICROREGIONS OF THE SOUTH MORAVIAN REGION

\author{
MGR. JAROSLAV BIOLEK ${ }^{1,2}$ \\ MGR. IVAN ANDRÁŠKO, PHD. ${ }^{1,2,3}$ \\ RNDR. ONDŘEJ ŠERÝ ${ }^{1}$ \\ Mgr. KAMILA KLEMEŠOVÁ ${ }^{1}$ \\ Mgr. Pavlína ZRƯSTOVÁ ${ }^{1}$ \\ DOC. RNDR. VÁCLAV TOUŠEK, CSC. ${ }^{1,2}$ \\ ${ }^{l}$ Geografický ústav ${ }^{1}$ Institute of Regional and Security Sciences \\ Prírodovédecká fakulta Faculty of Economics and Administration \\ Masarykova univerzita University of Pardubice \\ $\triangle$ Kotlářská 2, 61137 Brno, Czech Republic \\ E-mail: jaroslavbiolek@gmail.com geoganry@mail.muni.cz ondrej.sery@mail.muni.czkamilak@mail.muni.cz \\ pzrustova@seznam.cz tousek@porthos.geogr.muni.cz \\ ${ }^{2}$ Katedra geografie ${ }^{2}$ Department of geography \\ Př́rodovédecká fakulta Faculty of Science \\ Univerzita Palackého v Olomouci 1 Palacký University Olomouc \\ $\triangle$ 17. listopadu 12, 77146 Olomouc, Czech Republic \\ ${ }^{3}$ Geografický ústav $\quad{ }^{3}$ Institute of Geography \\ Slovenská akadémia vied Slovak Academy of Sciences \\ $\bowtie$ Štefánikova 49, 81473 Bratislava, Slovak Republic
}

\begin{abstract}
Anotace
Př́spěvek zkoumá strategie rozvoje mikroregionů Jihomoravského kraje z hlediska konceptualizace kvality života. Kvalita života predstavuje klićový koncept, který je v současnosti poměrně běžnou součásti strategii mistního a regionálniho rozvoje. Lze to dokumentovat také v prípadě strategicky plánovacich dokumentů na mikroregionálni úrovni. Předkládaná studie analyzuje, na prìkladu mikroregionů Jihomoravského kraje, jak je ve strategických dokumentech chápána kvalita života, jestli je vyjadřována explicitně, ke kterým strategickým cílům se vztahuje, jaké oblasti života jsou akcentovány apod. V závěru se zamýšlime nad dỉsledky vágního a povrchního ukotveni kvality života ve strategiich rozvoje.
\end{abstract}

\section{Kličová slova}

strategie rozvoje, kvalita života, mikroregion, Jihomoravský kraj, textová analýza 


\begin{abstract}
Annotation
The study investigates how quality of life is conceptualised within development strategies of the microregions from the South Moravian Region. Quality of life is the key concept that is currently the common part of local and regional development strategies. It can be documented in the case of strategic planning on a microregional level. The study analyses, on the example of the microregions from the South Moravian Region, how quality of life is interpreted in the strategic planning documents, if it is expressed explicitly, to which strategic goals it is related, which domains of quality of life are emphasised etc. In the conclusion, we consider the impacts of the superficial and vague use of quality of life concept in the development strategies.
\end{abstract}

Key words

development strategy, quality of life, microregion, South Moravian region, textual analysis

JEL classification: $R 58$

\title{
Úvod
}

Strategické plánování regionů a měst patří k hlavním nástrojům rozvoje, kterými tyto územně-správní celky disponují. Podoba, úloha a aplikace strategií a programů rozvoje není přesně definována, respektive neexistuje jasný konsensus (což vychází i z faktu neukotvení v legislativě), jak by měly tyto dokumenty vypadat, jak by měly vznikat, jaká je jejich struktura, jaké jsou jejich cíle, jak by měly být implementovány apod. Zvláštní př́ípad pak představují strategické dokumenty mikroregionů nebo dobrovolných svazků obcí, jež byly založeny za účelem dosažení společných cílů. Přestože je v zájmu těchto obcí spolupracovat, kooperace a koordinace společných cílů je značně obtížná a nezřídka vázne. Důvodem nemusí být pouze absence vhodných nástrojů strategického rozvoje, ale i problémy související s jejich praktickou aplikací.

Jak potvrzuje následující analýza, součástí koncepcí rozvoje je často i relativně populární téma kvality života. Role této problematiky ovšem není ve strategickém rozvoji explicitně dána, ani jednoznačně chápána. Z povahy věci, vzhledem k široce pojímané konceptualizace kvality života i rozvojových cílů, však vyplývá, že kvalita života je ve strategickém plánování často skloňována (např. v jednom z pilirrư - plán zdraví a kvality života) a její zlepšení vnímáno jako cíl rozvoje mikroregionu. Nicméně, at' už je kvalita života ve strategických dokumentech a programech rozvoje uvedena jen implicitně, řadíme ji $\mathrm{k}$ hlavním konceptům (spolu s trvalou udržitelností), které by měly být při tvorbě strategií i jejich realizacích zohledněny. Jde totiž o komplexní koncepci, jejíž teoretický, metodologický i realizační potenciál by mohl zvýšit relevanci i praktickou aplikaci strategických dokumentů, stejně jako zájem veřejnosti o společenské dění a jejich participaci na věcech veřejných.

Podle Labounkové et al. (2009) je ze strany tvůrců strategie vyžadován aktivní a otevřený přístup $\mathrm{k}$ občanům vytvářející důvěru $\mathrm{v}$ respektování názoru veřejnosti a v ovlivnitelnost společenského dění v obci, který může poté zvýšit jejich pocit sounáležitosti s místní komunitou lidí i prostředím regionu. Otázkou však zůstává, do jaké míry se v tomto ohledu daří strategie rozvoje realizovat a zlepšovat kvalitu života obyvatel prostřednictvím jejich zapojení do strategicky-plánovacího procesu.

Uvedené poznatky představují základní východiska naší studie, která analyzuje vybrané strategie rozvoje mikroregionů Jihomoravského kraje z perspektivy konceptualizace a ukotvení kvality života $\mathrm{v}$ strategicky-plánovacím procesu. Vzhledem k tomu, že text je prezentován jako „working paper“, není jeho primárním úkolem podrobný rozbor strategických dokumentů a související problematiky, nýbrž vstupní textová analýza a interpretace uchopení kvality života ve vybraných dokumentech. Výsledky analýzy chápeme především jako př́spěvek $\mathrm{k}$ diskuzi, jež by měla být nápomocná při tvorbě, implementaci a realizaci strategií rozvoje regionů a obcí, zahrnujících komplexní problematiku kvality života. 


\section{Popis analýzy}

Metodika našeho výzkumu má formu textové analýzy, jejíž nástroje jsou orientovány vzhledem k charakteru strategických dokumentů a konceptualizace kvality života. Jinými slovy, rozbor textů strategií rozvoje sleduje jejich metodologickou perspektivu, za jakým účelem je daná část vytvořena, co obsahuje a proč apod. (Aitken 2005). Zároveň je však kladen důraz na ukotvení kvality života v dokumentu, proto $\mathrm{v}$ prvé řadě obracíme pozornost na výskyt tohoto termínu $\mathrm{v}$ textu a dekonstruujeme jeho kontextuální uchopení a spojení s dalšími termíny a koncepty.

Prostřednictvím jednoduchého rozboru tedy kriticky pohlížíme na vybrané strategie rozvoje mikroregionů a sledujeme, $v$ jakých konotacích a významech je kvalita života chápána a zdali je o ní pojednáváno explicitně. $\mathrm{V}$ dalším bodě se zabýváme metodickým uchopením kvality života, tudíž analyzujeme, jakým způsobem jsou zkoumány životní podmínky v obcích mikroregionu a jejich percepce, resp. zdali je zohledněn i názor obyvatelstva a subjektivní hodnocení oblastí kvality života v mikroregionu. Následně rozebíráme uchopení kvality života ve strategické části rozvojových dokumentů, čili jestli je zlepšení kvality života jedním z pilířu či hlavních cílů rozvoje mikroregionu, zdali se jedná o holistickou koncepci kvality života, nebo je spojena pouze s některými oblastmi života, př́padně jestli a jakým způsobem je zajištěna participace občanů na realizaci akčního plánu.

Naší analýze bylo podrobeno 16 veřejně dostupných strategií rozvoje mikroregionů Jihomoravského kraje (z celkového počtu 69 v současnosti evidovaných mikroregionů). Bohužel na tomto místě je třeba zmínit, že právě veřejná nedostupnost a netransparentnost strategií rozvoje představuje jeden z hlavních problémů, jehož důsledky se dále promítají do dalších oblastí nejen při realizaci akčního plánu strategií. I přes tyto nedostatky $\mathrm{v}$ následující části popisujeme a interpretujeme výsledky naší analýzy vybraných strategických dokumentů, přičemž se snažíme akcentovat důležité a explicitně uvedené body spojené s kvalitou života.

\section{Výsledky analýzy}

V první řadě bychom rádi zmínili některé základní informace o daných strategiích rozvoje. $15 \mathrm{z} 16$ zkoumaných dokumentů mikroregionů Jihomoravského kraje nese název „strategie rozvoje“, „strategický plán“, nebo „integrovaná rozvojová strategie“ (výjimku představuje svým zaměřením Plán péče a rozvoje Lednicko-Valtického areálu). Většina strategií vznikla před vstupem ČR do EU, nebo byla $\mathrm{v}$ následujících letech aktualizována. Pokud jde o samotné mikroregiony, jejichž analýzou se zabýváme (seznam v Tab. 1), lze konstatovat, že se většinou jedná o venkovské regiony s různým stupněm periferity. Některé z nich mají zřejmé centrum, což se projevuje i v jejich názvu (např. Moravskokrumlovsko, Mikulovsko, nebo Kuřimka), jiné ho spíše postrádají a jejich označení je založeno na jiné geografické charakteristice (např. mikroregion Drahanská vrchovina, nebo Moravský kras). Nejednoznačný způsob vymezení regionů na základě venkovských atributů představuje hlavní paradox př́stupu k rozvoji venkova, ovlivňující i vlastní analýzu těchto oblastí a strategické plánování jejich rozvoje (např. Binek a kol. 2011, Hruška 2011).

Co se týče struktury vybraných strategických dokumenti̊, můžeme je rozdělit na dvě základní části, které jsou dále rozčleněny. První část se zpravidla nazývá analytická a většinou je chápána jako analýza mikroregionu a jeho př́rodních a sociálně-ekonomických podmínek. Bohužel text, který je pokládán za analýzu, můžeme téměř ve všech př́padech považovat spíše za popis nebo profil mikroregionu, členěný dle určitých fyzicko-geografických a sociálně-ekonomických charakteristik (jen ve 3 př́padech se nazývá profil). SWOT, popřípadě problémová analýza, bud' samostatně stojící, nebo připojená $\mathrm{k}$ deskriptivní části, sice shrnuje předchozí poznatky, na druhou stranu jako jediná část textu proniká hlouběji do podstaty problému objektivních podmínek kvality života $\mathrm{v}$ daných mikroregionech. Druhou významnou částí strategií rozvoje je pak strategický (návrhový) oddíl, který se rozděluje na různé fáze, dle následného postupu a konkretizace cílů. Tedy některé dokumenty obsahují pouze vize nebo návrh strategie, jiné rozvíjejí strategické cíle do akčních a realizačních plánů, nebo je skrze prioritní osy přetavují do konkrétních projektů. Z hlediska uchopení kvality 
života nás však především zajímají vize, prioritní osy a strategické cíle a jejich konceptualizace v kontextu této problematiky.

Jak už bylo řečeno, analytická část má především deskriptivní charakter a popisuje objektivní podmínky k životu v obcích. Avšak co subjektivní vnímání a evaluace těchto podmínek obyvateli obcí mikroregionů? Jakým způsobem je zohledněna subjektivní dimenze kvality života ve veřejně dostupných strategických plánech? Pouze 2 strategie rozvoje berou v potaz názory místních rezidentů (první prostřednictvím ankety, druhá na základě dotazníkového šetření), u dalších 4 pak bylo realizováno dotazníkové šetření se starosty obcí mikroregionů. Zbývajícím 10 chybí jakákoli reflexe názoru obyvatel, at' už v otázkách vztahu k okolnímu prostředí, nebo postojů $\mathrm{k}$ cílům rozvoje regionu.

Pokud se blížeji podíváme na použití termínu kvalita života, jen ve 3 dokumentech nenalezneme ani zmínku o tomto pojmu. Na druhou stranu, i když většina dokumentů terminologicky operuje s kvalitou života, de facto žádná strategie neuchopuje kvalitu života komplexně do hloubky nebo jednotně konceptuálně. Je pravda, že v rámci některých strategií rozvoje můžeme pozorovat implicitní pojímání kvality života $\mathrm{v}$ kontextu obecného blaha, ani $\mathrm{v}$ těchto př́ípadech však nelze mluvit o pojetí komplexním a multidimenzionálním, na jehož potřebu jsme upozornili již v předcházejících studiích (např. Andráško et al. 2012). Zvláštní případ představuje Strategie rozvoje mikroregionu Pernštejn, $\mathrm{v}$ rámci které bylo provedeno dotazníkové šetření a jež právě v analytické části spojuje kvalitu života se spokojeností. Nicméně pokud se už píše o kvalitě života v popisné a analytické ćásti, většinou se vztahuje ke dvěma šíre pojatým doménám kvality života. První můžeme charakterizovat jako životní podmínky a zahrnuje životní prostředí a kvalitu bydlení, popř́ípadě infrastrukturu a občanskou vybavenost. Druhá doména se podle vymezení orientuje více na lidské zdroje a zdravotní péči, respektive se zabývá společenským a komunitním životem v obcích mikroregionu. Toto rozdělení je ovšem značně zjednodušující vzhledem k obtížnosti rozlišení jednotlivých oblastí mezi sebou. Kvalita života se tak často objevuje v nejrůznějších konotacích; $v$ jednom dokumentu je kupříkladu zeširoka pojímána jako obecné blaho a zároveň odkazuje na kvalitu bydlení. 
Tab. 1: Seznam veřejně dostupných strategii rozvoje mikroregionů Jihomoravského kraje

\begin{tabular}{|c|c|c|c|}
\hline \begin{tabular}{|c|} 
Název \\
mikroregionu
\end{tabular} & Název dokumentu & $\begin{array}{c}\text { Rok } \\
\text { zpracování }\end{array}$ & Dostupné na: \\
\hline Hustopečsko & Strategie rozvoje & 2007 & $\frac{\text { http://www.hornibojanovice.cz/hbsunny/2ud/pdf/strategierozvojeh07. }}{\text { pdf }}$ \\
\hline Podluží & Strategie rozvoje & 2005 & $\begin{array}{c}\text { http://www.podluzi.cz/dokumenty/cat view/24-dokumenty-regionu/67 } \\
\text { strategie-rozvoje-regionu-podluzi/68-strategie-rozvoje-2005-2010 }\end{array}$ \\
\hline PORTA & \begin{tabular}{|c|} 
Integrovaná \\
rozvojová strategie
\end{tabular} & 2002 & http://www.regionporta.cz/index.php?typ=OBA\&showid=38 \\
\hline Mikulovsko & Strategie rozvoje & 2004 & http://www.mikulovskoregion.cz/data/1656.pdf \\
\hline \begin{tabular}{|c|} 
Lednicko- \\
valtický areál
\end{tabular} & Plán péče a rozvoje & 1999 & $\begin{array}{c}\text { http://www.Iva.cz/.files/plan-pece-a-rozvoje-lednicko-valtickeho- } \\
\text { arealu.pdf }\end{array}$ \\
\hline Cezava & Strategie rozvoje & 2002 & $\begin{array}{c}\text { http://www.region- } \\
\text { cezava.cz/resources/upload/data/3 Strategie rozvoje.pdf }\end{array}$ \\
\hline Moravský kras & Strategický plán & 1999 & http://www.spolekmoravskykras.cz/region-moravsky-kras/plan-rozvoje/ \\
\hline $\begin{array}{l}\text { Drahanská } \\
\text { vrchovina }\end{array}$ & Strategický plán & 2009 & $\begin{array}{c}\text { http://dataplan.info/img upload/7bdb1584e3b8a53d337518d988763f8d/ } \\
\text { SPUR mikroregionu Drahanska Vrchovina 2009.pdf }\end{array}$ \\
\hline Svitava & Strategie rozvoje & 2008 & http://www.svazeksvitava.cz/file.php?nid=440\&oid=1246416 \\
\hline $\begin{array}{l}\text { Moravsko- } \\
\text { krumlovsko }\end{array}$ & Rozvojová strategie & 2007 & imlovsko.cz/dok \\
\hline Časnýr̆ & Rozvojová strategie & 2005 & $\frac{\text { http://www.spolekmoravskykras.cz/create file.php\%3Fid\%3D265+\&cd=1 }}{\& h l=e n \& c t=c \mid n k \& g l=c z}$ \\
\hline Bzenecko & $\begin{array}{c}\text { Integrovaná } \\
\text { rozvojová strategie }\end{array}$ & 2002 & http://www.bzenecko.cz/dokument/strabz02.htm \\
\hline Kuřimka & $\begin{array}{c}\text { Integrovaná } \\
\text { rozvojová strategie }\end{array}$ & 2006 & http://www.kurim.cz/cs/obcan/rozvoj-mesta/mikroregion-kurimka.htm \\
\hline Rakovec & Strategie rozvoje & 2003 & http://www.rousinov.cz/soubory/ostatni/mr analyza.pdf \\
\hline Mezihoří & Strategie rozvoje & 2009 & $\begin{array}{c}\frac{\text { http://www.somezihori.cz/cze/rozvojova-strategie-so-mezihori-2007- }}{\underline{2013-p 712}} \\
\end{array}$ \\
\hline Pernštejn & Strategie rozvoje & 2007 & $\frac{\text { http://www.pernstejnsko.cz/obrazky2/Strategie rozvoje\%20Pernstejn }}{\text { INAL.pdf }}$ \\
\hline
\end{tabular}

Zdroj: Vlastní zpracování, citováno 29/04/2013

Jisté rozdíly však lze pozorovat mezi pojetím kvality života v analytické a strategické (návrhové) části vybraných dokumentů. Lapidárně řečeno, $v$ druhé části strategií se kvalita života častěji pojí s aspekty zdraví a sociálními hledisky. Mimoto je ve strategické části kvalita života v 5 prŕpadech uvedena explicitně jako hlavní piliř nebo cíl rozvoje. Pokud je kvalita života chápána jako jeden ze základních cílů rozvoje, na jehož základě jsou vymezeny opatření a dílčí aktivity, vztahuje se opět k sociální a zdravotní péči, společenskému životu, rozvoji lidských zdrojů, službám, nebo občanské vybavenosti. V druhé perspektivě se především používá formulace „zvýššní kvality života“ a v tomto př́padě je kvalita života vedle trvalé udržitelnosti aplikována jako všeobecně uznávaný princip, který také, bohužel, postrádá teoretické ukotvení.

Lze tedy konstatovat, že, i přes jisté snahy komplexním způsobem konceptualizovat kvalitu života ve vybraných strategických dokumentech, uchopení tohoto fenoménu tíhne k vágnosti a nejednoznačnosti. Ačkoliv bychom mohli prohlásit, že jakýkoli pokus zahrnout kvalitu života do strategií rozvoje je veřejně prospěšný, nemusí být tento fakt vždy pravdivý.

\section{Závěr}

Výsledky textové analýzy potvrzují naše předpoklady a ukazují, že uchopení kvality života ve veřejně dostupných strategických plánech mikroregionů Jihomoravského kraje je velmi časté, ale značně problematické. Třebaže o kvalitě života pojednávají téměř všechny strategie rozvoje, její pojetí se značně různí a nepředstavuje ani komplexní a multidimenzionální koncepci, ani jednotný dílčí koncept. Pokud už je termín kvalita života ve strategických dokumentech zmíněn, zpravidla se 
v daném kontextu vztahuje bud' k životnímu prostředí, bydlení, infrastruktuře a občanské vybavenosti, nebo ke zdravotní a sociální péči, lidským zdrojům a společenskému dění v obcích mikroregionů. Kvalita života je dokonce $\mathrm{v}$ pěti strategiích rozvoje koncipována jako hlavní cíl rozvoje, respektive princip, podle kterého by se měl rozvoj mikroregionu ř́dit.

Velmi častým problémem vybraných strategií je mimo jiné deskriptivní charakter analýz, který nejde do hloubky věci a může degradovat následnou tvorbu strategie, tedy i zaměření na relevantní oblasti kvality života. I díky tomu je tento komplexní koncept jen těžko pochopitelný a obtížně uchopitelný, tudíž nejen zastupitelé, ale i odborníci, kteří vytvářejí jednotlivé strategie, se špatně vypořádají s těmito obtížemi. S kvalitou života se tak operuje vágně, zvláště při formulaci vizí a deklamaci cílů, což snižuje vážnost i závažnost celé problematiky. Jinými slovy, i když jsou programy rozvoje vytvářeny především pro lidi, resp. na zlepšení jejich kvality života, nejsou tito do jejich realizace zapojováni, což se poté odráží v nezájmu veřejnosti o tyto dokumenty. Potvrzuje to i fakt, že pouze $\mathrm{v}$ rámci dvou strategií z šestnácti bylo provedeno dotazníkové šetření s občany, poprípadě anketa, která zohledňovala jejich názory a postoje ke kvalitě života. Mimochodem podobné problémy jsme zaznamenali již v naší předešlé studii mikroregionu Jindřichohradecka a př́slušné strategie rozvoje (Andráško et al. 2012).

Je důležité zmínit, že výše uvedené nedostatky jsou do značné míry zaviněny pluralitou chápání kvality života. Jako naléhavá se proto jeví potřeba tuto problematiku jednoznačněji odborně uchopit a umožnit tak specifikaci a analýzu relevantních problémů a navrhování jejich řešení. V oblasti strategického plánování jde tedy především o zodpovězení otázky, jakým způsobem implementovat kvalitu života do strategií rozvoje tak, aby reálně přispívaly ke zlepšení života obyvatel obcí a regionů.

\section{Literatura}

[1] AITKEN, S. C. Textual analysis: reading culture and context. In Methods in Human Geography. Harlow: Pearson Education Limited, 2005, s. 233-249.

[2] ANDRÁŠKO, I., BIOLEK, J., HORÁKOVÁ, J. Mikroregion a kvalita života - př́padová studie mikroregionu Jindřichohradecko. In $X V$. mezinárodní kolokvium o regionálních vědách. Sborník přispěvkio. Brno: Masarykova univerzita, 2012, s. 529-537.

[3] BINEK, J. a kol. Synergie ve venkovském prostoru - Paradoxy rozvoje venkova. Brno: GaREP Publishing, 2011.

[4] HRUŠKA, V. České strategické plánování rozvoje venkova v politickém a plánovacím diskurzu. Urbanismus a územní rozvoj, roč. 15, 2011, č. 3, s. 7-12.

[5] LABOUNKOVÁ, V., PU゚ČEK, M., ROHREROVÁ, L. a kol. Metodická přiručka pro zpracování strategických rozvojových dokumentů mikroregionů. Brno: Ministerstvo pro místní rozvoj, Ústav územního rozvoje, 2009, 47 s.

Tento př́spěvek byl zpracován v rámci řešení projektu „Projevy globální environmentální změny v krajinné sfére Země (MUNI/A/0966/2009)“ (50\%) a projektu GA ČR „Urbánní a suburbánní kvalita života: geografický pohled“ (50\%). 